\author{
Aleksandra Szpulak \\ Uniwersytet Ekonomiczny we Wrocławiu \\ e-mail: aleksandra.szpulak@ue.wroc.pl
}

\title{
MODELOWANIE OPERACYJNEGO \\ KAPITAŁU OBROTOWEGO Z ZASTOSOWANIEM ARKUSZA KALKULACYJNEGO. BUDOWA I WERYFIKACJA MODELU
}

\begin{abstract}
Streszczenie: Typowy model stosowany w krótkookresowym zarządzaniu finansowym nastawionym na maksymalizowanie wartości przedsiębiorstwa to model analityczny, jak np. model zbudowany przez [Sartoris, Hill 1983; Kim, Chung 1990]. Założenia przyjęte przy budowie modeli analitycznych, tj. ciągłość wpływów i wydatków oraz związanie wielkości przepływów pieniężnych bezpośrednio z wielkością sprzedaży, powoduje, że prognozy wpływów i wydatków gotówkowych zbudowane na ich podstawie są nietrafne i obciążone. Przydatność takiego modelu w praktyce jest co najmniej wątpliwa. W artykule zaprezentowano budowę i weryfikację autorskiego modelu operacyjnego kapitału obrotowego, który pozwala na budowę prognoz operacyjnych wpływów i wydatków gotówkowych o lepszej jakości. Cel ten osiągnięto, modelując operacyjny kapitał obrotowy z zastosowaniem arkusza kalkulacyjnego w miejsce klasycznych funkcji analitycznych.
\end{abstract}

Słowa kluczowe: operacyjny kapitał obrotowy, przepływy pieniężne netto, prognoza, arkusz kalkulacyjny.

DOI: $10.15611 / \mathrm{ekt} .2014 .4 .02$

The very essence of a business is to increase wealth by means of its operating cycle

Pierre Vernimmen

\section{Wstęp}

Zagadnienia związane z zarządzaniem operacyjnym kapitałem obrotowym przedsiębiorstwa stanowiły i stanowią jeden z ważniejszych problemów współczesnych finansów. Efektywność zarządzania tym kapitałem, tj. kształtowanie odpowiedniej struktury i wielkości operacyjnych aktywów obrotowych oraz struktury i wielkości 
źródeł finansowania tych aktywów, wpływa bowiem zarówno na płynność finansową przedsiębiorstwa, jak i na jego efektywność finansową.

Wśród wielu wątków poruszanych w literaturze krajowej i światowej tego tematu można wskazać następujące współcześnie dominujące: (i) optymalizacja zarządzania operacyjnym kapitałem obrotowym w świetle kryterium maksymalizacji wartości przedsiębiorstwa, (ii) identyfikacja czynników kształtujących poziom i strategie kapitału obrotowego, (iii) określenie relacji między kapitałem obrotowym a efektywnością przedsiębiorstwa oraz (iv) badania wpływu inwestycji w kapitał obrotowy na wartość przedsiębiorstwa. Spośród wymienionych tu obszarów badawczych badania prowadzone w pierwszym z nich mają charakter badań teoretycznych, a w pozostałych badań empirycznych. Poruszany w artykule temat związany $\mathrm{z}$ modelowaniem operacyjnego kapitału obrotowego jest umiejscowiony w pierwszym z ww. obszarów.

Celem artykułu jest zaprezentowanie budowy oraz weryfikacji autorskiego finansowego modelu operacyjnego kapitału obrotowego, opisanego przez zestaw równań gotowych do użycia w arkuszu kalkulacyjnym Excela. Przy budowie modelu w miejsce tradycyjnych modeli analitycznych zastosowano podejście arkusza kalkulacyjnego. Opierając się bowiem na opisanych w literaturze korzyściach stosowania tego podejścia $\mathrm{w}$ długookresowym zarządzaniu finansami przedsiębiorstwa (zob. np. [Brealey, Myers 1996, s. 799-800; Copeland i in. 2005, s. 506]), w badaniach postawiono hipotezę głoszącą, iż budowa finansowego modelu operacyjnego kapitału obrotowego w arkuszu kalkulacyjnym może znacznie poprawić jego jakość w porównaniu z teoretycznymi modelami analitycznymi, dzięki czemu tak zbudowany model stanie się efektywniejszym narzędziem zarządzania operacyjnym kapitałem obrotowym. Przy budowie modelu w arkuszu kalkulacyjnym stosowano metodologię opisaną przez [Charnes 2007].

Artykuł składa się z 6 części. W części drugiej uzasadniono potrzebę zastosowania podejścia innego niż analityczne w obszarze zarządzania kapitałem pracującym. W kolejnej części scharakteryzowano model oraz wyspecyfikowano jego założenia. Następnie, w części 4, wyprowadzono z definicji zmiennych ich równania tożsamościowe, które można wpisać do arkusza kalkulacyjnego. Kolejna, 5, część dotyczy oceny modelu - w pierwszej kolejności na ocenę jakości modelu składa się weryfikacja, czyli sprawdzenie poprawności zapisu matematycznego i wpisanych na jego podstawie formuł arkusza kalkulacyjnego Excel.

Ujęcie problematyki operacyjnego kapitału obrotowego w niniejszym artykule jest nietypowe nie tylko z powodu stosowania innego niż analityczne podejście do modelowania tego kapitału, ale także dlatego, że dokonano operacjonalizacji tego zagadnienia w warsztacie badawczym operacyjnych przepływów pieniężnych w miejsce powszechnie stosowanych zasobów operacyjnych aktywów obrotowych i operacyjnych zobowiązań bieżących ${ }^{1}$. Wykorzystanie operacyjnych przepływów

${ }^{1}$ Definicje i pomiar inwestycji netto w operacyjny kapitał obrotowy przedsiębiorstwa sformułowane na podstawie operacyjnych przepływów pieniężnych przedstawiono w pracy [Szpulak 2014]. 
pieniężnych umożliwia ocenę efektywności finansowej zarządzania operacyjnym kapitałem obrotowym na podstawie wartości.

\section{Potrzeba nowego podejścia do modelowania operacyjnego kapitału obrotowego}

Podstawowym narzędziem zarządzania finansami przedsiębiorstwa jest finansowy model teoretyczny, który opisuje analizowane zjawisko. Tradycyjnie taki model jest modelem analitycznym. Model analityczny wprawdzie zwięźle i elegancko opisuje zachowanie zmiennych i zależności między nimi, jednocześnie jednak wprowadza w tym zakresie tak wiele ograniczeń, że choć jest skuteczny w poznawaniu natury zjawisk, to w praktyce może być mało przydatny ze względu na jego duży błąd i stosunkowo małą elastyczność. W dobie powszechnego dostępu do mocnych komputerów wyposażonych w rozliczne programy służące analizie danych podejście analityczne zaczyna być wypierane przez alternatywne modelowanie w arkuszu kalkulacyjnym (tzw. spreadsheet approach). Finansiści powszechnie stosują to podejście przy budżetowaniu kapitałowym, planowaniu finansowym, wycenie przedsiębiorstw czy zarządzaniu gotówką (zob. np. [Brealey, Myers 1996, s. 800-805, 831-838; Pluta 2003, s. 59-65, 143-203]).

W krótkookresowym zarządzaniu finansowym modele finansowe zbudowane z zastosowaniem arkusza kalkulacyjnego są wykorzystywane głównie w obszarze zarządzania płynnością finansową, pomijany jest zaś aspekt efektywności finansowej zarządzania kapitałem obrotowym. Aspekt płynności finansowej był faktycznie newralgiczny w minionym stuleciu ( $\mathrm{tj}$. w latach 50. w USA, w latach 90. w Polsce), wówczas bowiem przedsiębiorstwa miały pewne trudności z dostępem do środków finansowych i z powodu utraty płynności finansowej upadały nawet przedsiębiorstwa rentowne. Obecnie jednak rynki finansowe są na tyle dobrze rozwinięte, że podmiot, który działa efektywnie, nie powinien mieć trudności z dostępem do środków finansowych. Wydaje się zatem właściwe przeniesienie perspektywy krótkoterminowego zarządzania finansowego z płynności finansowej na efektywność finansową. W tym nurcie badań dominujące są jednak w dalszym ciągu finansowe modele analityczne.

W modelach analitycznych stosowanych do oceny efektywności zarządzania kapitałem obrotowym, zbudowanych np. przez np. [Sartoris, Hill 1983; Kim, Chung 1990], zakłada się, że operacyjne wpływy gotówkowe są funkcją sprzedaży, a operacyjne wydatki gotówkowe stanowią odsetek wpływów gotówkowych. Ponadto wpływy i wydatki gotówkowe wynikające ze sprzedaży są ciągłe, czyli ta sama pętla wpływów i wydatków powtarza się każdego dnia działalności operacyjnej. Oba te założenia powodują, że operacyjne wpływy i wydatki co do ich wielkości oraz momentów ich pojawiania się znacznie odbiegają od rzeczywistości, co jednocześnie powoduje, że błąd modelu analitycznego jest bardzo duży, a prognozy wyznaczone na jego podstawie są nie tylko nietrafne, ale i obciążone. Dla zilustrowania rozbieżności pomiędzy przepływami występującymi w rzeczywistości oraz przepływami 
opisywanymi przez modele analityczne prezentowane w pracach (np. [Sartoris, Hill 1983; Kim, Chung 1990]) na rys. 1 zestawiono te przepływy w postaci NCF, czyli przepływów pieniężnych netto.

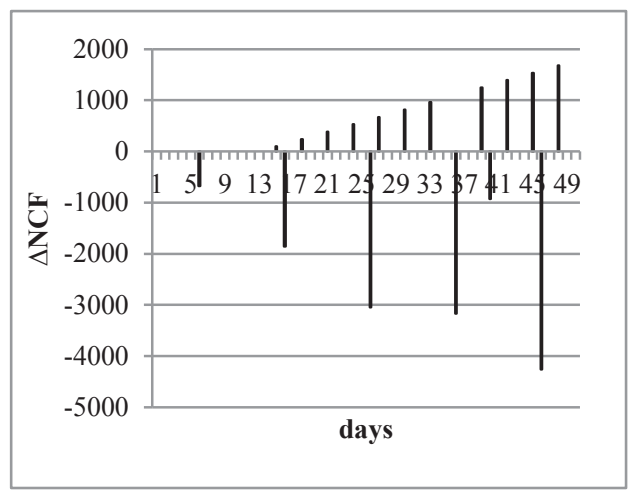

Panel (a)

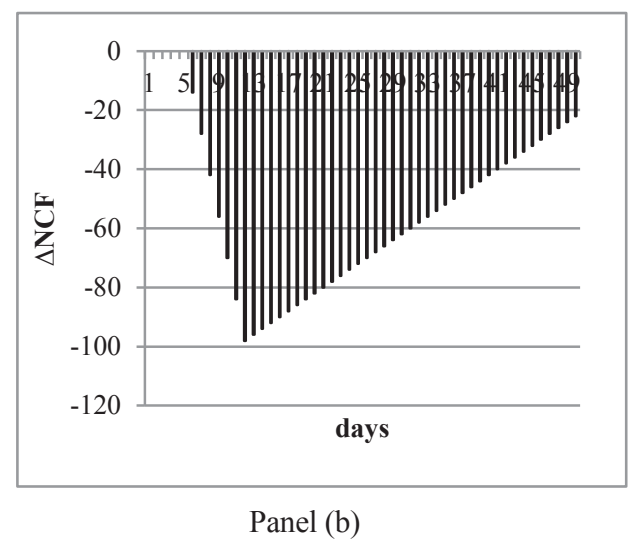

Panel (b)

Rys. 1. Przepływy pieniężne netto wygenerowane w ciągu 50 dni działalności operacyjnej w warunkach liniowego trendu ze sprzedaży w panelu (a) zbliżone do przepływów rzeczywistych, a w panelu (b) - zakładając ciągłe przepływy pieniężne wynikające ze sprzedaży

Źródło: opracowanie własne.

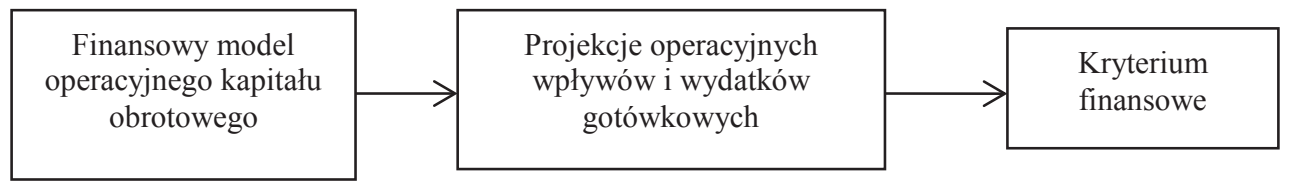

Rys. 2. Finansowe zarządzanie operacyjnym kapitałem obrotowym w warunkach pewności

Źródło: opracowanie własne.

Aby wyeliminować opisane wady podejścia analitycznego, w artykule zaprezentowano budowę autorskiego teoretycznego modelu operacyjnego kapitału obrotowego przedsiębiorstwa, wykorzystując w tym celu możliwości arkusza kalkulacyjnego. Zbudowany w postaci formuł arkusza kalkulacyjnego model może służyć do budowy krótkookresowych projekcji operacyjnych wpływów i wypływów gotówkowych. Projekcje tworzone są w drodze symulacji na zbudowanym modelu w zdefiniowanych przez użytkownika warunkach obejmujących zmienne znajdujące się na wejściu do modelu. Na podstawie finansowej oceny projekcji przepływów gotówkowych przedsiębiorstwo podejmuje decyzje spójne z celem finansowym przedsiębiorstwa, w szczególności mogą to być decyzje optymalne w świetle tego celu (zob. rys. 2). Niniejszy artykuł jest jednym z cyklu artykułów poświęconych zarzą- 
dzaniu operacyjnym kapitałem obrotowym zorientowanemu na maksymalizowanie wartości przedsiębiorstwa.

\section{Ogólna charakterystyka i założenia modelu}

Skonstruowany finansowy model jest symulacyjnym modelem prognostycznym, którego równania są matematycznym zapisem definicji poszczególnych zmiennych tworzących operacyjne przepływy pieniężne. Model umożliwia analizę operacyjnych wpływów i wydatków gotówkowych generowanych każdego dnia w cyklu operacyjnym przedsiębiorstwa oraz ich sumy obserwowanej w horyzoncie prognozy i dowolnym podokresie horyzontu prognozy.

Na wejściu do modelu znajduje się popyt opisany dowolnym modelem tendencji rozwojowej $f(t)$ :

$$
D_{t}=D_{0} f(t),
$$

gdzie: $D_{0}$ - popyt w okresie $t=0, f(t)$ - model tendencji rozwojowej, taki że $f(t) \geq 0$.

$\mathrm{Na}$ wyjściu z modelu uzyskujemy operacyjne przepływy pieniężne $C F^{+}{ }_{t}{ }_{i} C F^{-}$. $\mathrm{W}$ modelu w postaci parametrów uwzględniono zmienne decyzyjne występujące w obszarze zarządzania operacyjnym kapitałem obrotowym (lista uwzględnionych zmiennych znajduje się w opisie rys. 3). To właśnie zmiana poziomu zmiennych decyzyjnych pozwala tworzyć projekcje finansowe operacyjnych wpływów i wydatków gotówkowych.

Podczas konstrukcji modelu przyjęto następujące założenia:

Założenie 1. Działalność operacyjna przedsiębiorstwa jest rozpatrywana jako zbiór projektów inwestycyjnych, z których każdy jest ograniczony do jednej linii produkcyjnej i jednego odbiorcy (lub homogenicznej grupy odbiorców).

Zatożenie 2. Przedsiębiorstwo zna popyt na swój produkt.

Założenie 3. Przedsiębiorstwo dysponuje mocami produkcyjnymi koniecznymi do zaspokojenia popytu na swój produkt.

Założenie 4. Odbiorcy i dostawcy ściśle przestrzegają warunków współpracy z przedsiębiorstwem.

Założenie 5. Przedsiębiorstwo ściśle przestrzega przyjętych zasad organizacji produkcji.

Ograniczenie prognozy do jednego produktu i jednego odbiorcy jest uzasadnione indywidualizowaniem oferty przedsiębiorstwa i/lub podejmowanymi z odbiorcami negocjacjami handlowymi. Powstające w ten sposób prognozy cząstkowe można łączyć w prognozy globalne poprzez zwykłe sumowanie. Założenia 2-3 są naturalną konsekwencją rozpatrywania prognoz krótkookresowych, przyjęcie tych założeń pozwala na ekstrapolację modelu bez obawy, że niemożliwe będzie zaspokojenie prognozowanego popytu. Wyłączenie niepewności z analizy (czego dotyczą założenia 2, 4-5) jest zgodne z przyjętą za [Charnes 2007] metodologią budowy modeli 
finansowych w arkuszu kalkulacyjnym i jest uzasadnione na etapie budowy modelu. W kolejnych etapach modelowania, tj. modelowaniu ryzyka, odstępuje się od tych założeń. Pomimo wyłączenia $\mathrm{z}$ analizy niepewności uwzględniono w modelu rezerwy operacyjnych aktywów bieżących, ponieważ ich utworzenie z definicji kształtuje poziom operacyjnego kapitału obrotowego w przedsiębiorstwie.

Zasady współpracy z odbiorcami i dostawcami oraz zasady organizacji produkcji determinują wielkość opóźnienia w czasie zmiennych, czyli tzw. leadtime. Wielkości te mogą być jednak dowolnie kształtowane przez użytkownika modelu i dlatego nie mają charakteru założeń. Poniżej wyszczególniono kolejno wszystkie obowiązujące zasady:

1. W bieżącym dniu przyjmowane do realizacji są zamówienia złożone wcześniej, sprzedaż jest równa wielkości zamówienia, a należność powstaje w dniu sprzedaży.

2. Planowanie produkcji polega na równomiernym rozłożeniu obciążenia linii produkcyjnej na każdy dzień produkcji, a obciążenie to wynika z przyjętych do realizacji zamówień.

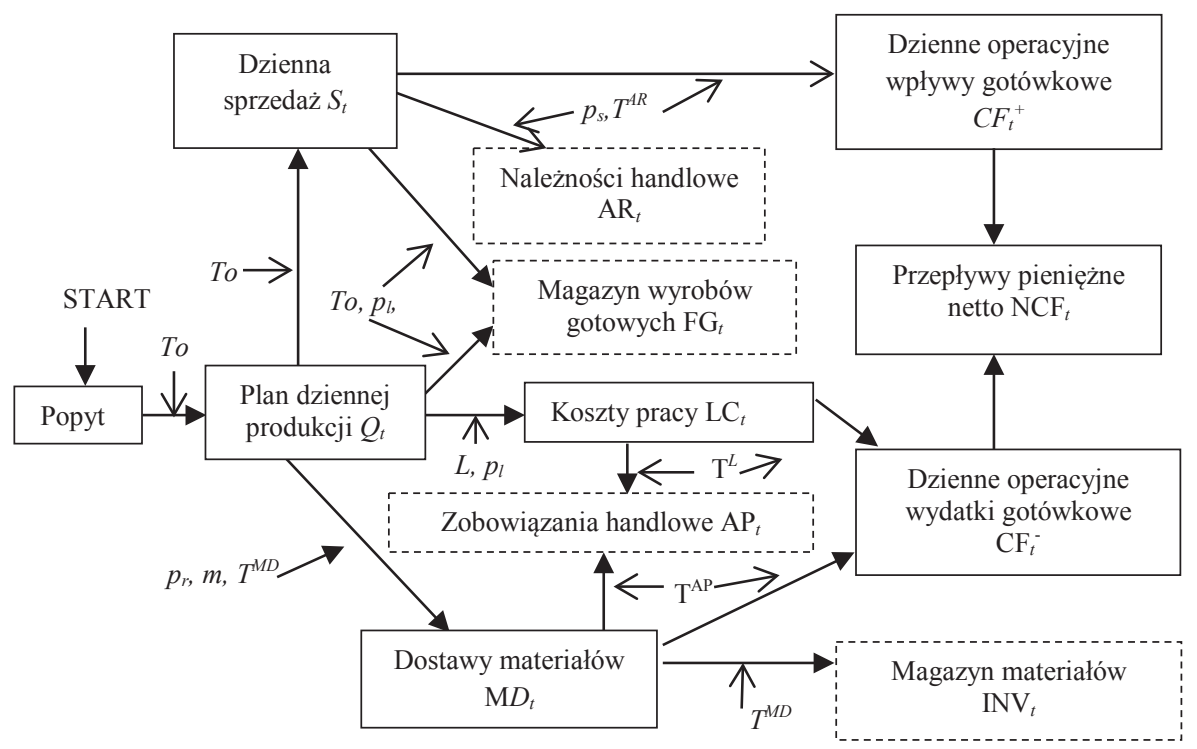

$T_{O}$ - cykl zamówień, $p_{m}$ - jednostkowa cena materiałów, $p_{1}$ - jednostkowa cena pracy, $m$ - jednostkowe zużycie materiałów, $p_{s}$ - jednostkowa cena sprzedaży, $T^{4 R}$ - okres odroczenia płatności należności, $T^{M D}$ - cykl zamówień materiałów, $T^{A P}$ - okres odroczenia płatności zobowiązań handlowych, $L$ - okres rozliczania wynagrodzeń, $T^{L}$ - okres odroczenia płatności wynagrodzeń.

Linią przerywaną zaznaczono zmienne ujęte w bilansie, a linią ciągłą zmienne nieobserwowane w sprawozdaniach finansowych.

Rys. 3. Finansowy model operacyjnego kapitału obrotowego

Źródło: opracowanie własne. 
3. Zamówienia na materiały składane są w stałym cyklu, w dniu realizacji zamówienia powstaje zobowiązanie.

4. Odbiorcy regulują należności, a przedsiębiorstwo płaci swoje zobowiązania dokładnie ostatniego dnia udzielonego kredytu kupieckiego.

5. Wynagrodzenie pracowników płatne jest $\mathrm{z}$ dołu.

Schemat modelu przedstawiono na rys. 3 .

\section{Równania modelu}

Na rysunku 4 przedstawiono przykładową pętlę operacyjnych wpływów i wydatków gotówkowych opisaną modelem zdefiniowanym równaniami (2)-(8).

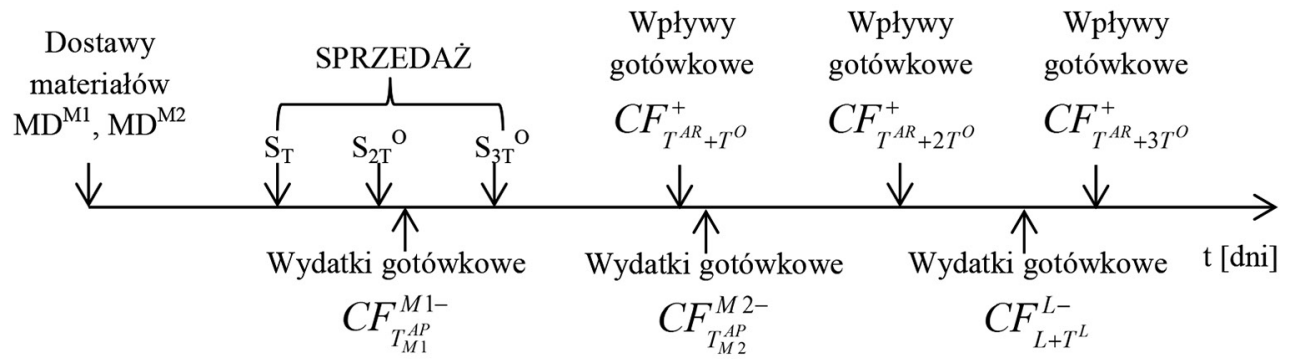

gdzie $M 1$ oraz $\mathbf{M} 2$ oznaczają rodzaje materiałów, $C F^{+}$to wpływy gotówkowe ze sprzedaży, $C F^{-}$to wydatki gotówkowe związane odpowiednio z zapłatą za materiały $M 1, M 2$ oraz pracę $L$, opis pozostałych symboli zob. rys. 3 .

Rys. 4. Przykładowa pętla przepływów gotówkowych,

Źródło: opracowanie własne.

Produkcja

Produkcja realizowana jest według planu produkcji. Zgodnie z zasadami współpracy z odbiorcami i dostawcami planowanie produkcji polega na równomiernym obciążeniu linii produkcyjnej na każdy dzień produkcji. W bieżącym dniu przyjmowane do realizacji są zamówienia złożone dnia poprzedniego. Zamówienia składane są w stałym cyklu równym $T^{O}$ :

$$
S_{t, i}=\left\{\begin{array}{l}
\sum_{t=(i-1) T^{O}+1}^{i T^{O}} D_{0} f(t) \quad t=i T^{O}, \\
0 \quad t \neq i T^{O}
\end{array},\right.
$$

gdzie: $S_{i, t}$-zamówienie na produkty w jednostkach naturalnych, $t$ - okres prognozy, $t=1,2, \ldots T, i$-numer zamówienia, $i=1,2, \ldots ; D_{t}-$ dzienny popyt, $T^{0}-$ cykl zamówień. 
Okres $T^{O}$ jest jednocześnie okresem całkowitej realizacji zamówienia, dlatego dzienna produkcja wynosi:

$$
Q_{t, i}=\left\{\begin{array}{c}
\frac{S_{i}}{T^{O}} \quad t<i T^{O} \\
S_{i}-\sum_{t=(i-1) T^{O}+1}^{i T^{O}-1} Q_{t, i} \quad t=i T^{O}
\end{array},\right.
$$

gdzie: $Q_{t, i}-$ dzienna produkcja w jednostkach naturalnych wynikająca z zamówienia $\mathrm{S}_{i}$.

\section{Zamówienia materiałów do produkcji - dostawy}

W produkcji wykorzystywanych jest $r$ materiałów, $r=M 1, M 2$, .... Zamówienia na materiały składane są w stałym cyklu wynoszącym $T_{r}^{M D}$ dni, zamówienie składane jest na dzień przed rozpoczęciem produkcji i jest realizowane w kolejnym dniu. Zamówienia MD w kolejnych dniach $t$ wynoszą:

$$
M D_{t, j}^{r}=\left\{\begin{array}{l}
\sum_{t=(j-1) T_{r}^{M D}+1}^{j T_{r}^{M D}} Q_{t} \cdot m_{r} \quad t=(j-1) T_{r}^{M D}+1 \\
0 \quad t \neq(j-1) T_{r}^{M D}+1
\end{array},\right.
$$

gdzie: $M D_{t, j}^{r}$ - zamówienie materiałów do produkcji; $T_{r}^{M D}-$ cykl zamówień materiałów [w dniach]; $j$ - numer zamówienia materiałów, $j=1,2, \ldots ; r$ - rodzaj materiałów, $r=1,2, \ldots ; m_{r}-$ zużycie materiału w jednostkach naturalnych na jednostkę produkcji.

\section{Koszty pracy}

Wynagrodzenia $L C$ naliczane są z dołu, za okres oznaczony przez L:

$$
L C_{t, g}=\left\{\begin{array}{c}
O \quad t \neq g L \\
\sum_{t=(g-1) L+1}^{g L} Q_{t} p_{l} \quad t=g L
\end{array},\right.
$$

gdzie: $L C_{t}$ - koszty pracy; $p_{l}$ - jednostkowy koszt robocizny; $g$ - numer wypłaty, $g=1,2, \ldots ; L-$ cykl rozliczania wynagrodzeń [w dniach].

\section{Operacyjne wydatki gotówkowe}

Wydatki gotówkowe są związane z regulowaniem zobowiązań przedsiębiorstwa $\mathrm{z}$ tytułu dostaw materiałów $\mathrm{CF}^{r-} \mathrm{i}$ wynoszą:

$$
C F_{t}^{r-}=p_{m r} M D_{t-T_{r}^{A P}+1}^{r} \quad t \geq T_{r}^{A P},
$$


gdzie: $T_{r}^{A P}$ - okres odroczenia płatności zobowiązań z tytułu dostaw materiałów;

$p_{m r}$ - cena jednostki materiałów.

Wydatki przedsiębiorstwa związane $\mathrm{z}$ regulowaniem wynagrodzenia za pracę $\mathrm{CF}^{\mathrm{L}-}$ wynoszą:

$$
C F_{t}^{L-}=L C_{t-T^{L}+1} \quad t \geq T^{L},
$$

gdzie: $T^{L}$ - okres odroczenia płatności wynagrodzeń.

\section{Operacyjne wpływy gotówkowe}

Wpływy gotówkowe są realizowane w przedsiębiorstwie z tytułu sprzedaży kredytowej:

$$
C F_{t}^{+}=p_{s} S_{t-T^{A R}+1} \quad t \geq T^{A R},
$$

gdzie: $C F_{t}^{+}$- wpływy gotówkowe w dniu $t ; T^{4 R}$ - okres odroczenia płatności należności; $p_{s}$ - jednostkowa cena sprzedaży.

\section{Weryfikacja modelu}

Zbudowany model operacyjnego kapitału obrotowego sprawdzono pod kątem poprawności zapisu matematycznego, będącego odzwierciedleniem formuł arkusza kalkulacyjnego Excel, rozwiązując przykład numeryczny. Obliczono kolejnych 24 wartości zmiennych: $S_{t^{i} i} Q_{t, i} L C_{t, g^{\prime}} M D^{r}{ }_{{ }^{2} j} C F_{t}^{+}$oraz $C F_{t}^{-}$. Przyjęto następujące hipotetyczne wartości parametrów modelu: $T o=3, r=2, T_{1}^{M D}=6, T_{2}^{M D}=12, T^{4 R}=$ 14, $T_{1}^{A P}=6, T_{2}^{A P}=10, L=20, T^{L}=10, m_{M 1}=2, m_{M 2}=2, p_{m M 1}=1, p_{m M 2}=1, p_{l}=1$, $p_{s}=4, M 1_{0}=10, M 2_{0}=10, F G_{0}=15$. Popyt opisano funkcją $D_{t}=2 t$. Wyniki obliczeń podsumowano $\mathrm{w}$ tab. 1.

Przeanalizujemy wybrane wiersze tab. 1 .

Przedsiębiorstwo zna popyt na swój produkt, zna także cykl zamówień wynoszący $T^{O}=3$ dni i na tej podstawie wyznacza kolejne zamówienia $\mathrm{S}_{i, t}$. Jednocześnie przedsiębiorstwo tworzy rezerwę wyrobów gotowych w wysokości $F G_{0}=15$ szt., a wielkość ta dodawana jest do pierwszego zamówienia. Ostatecznie zamówienie wynosi $S_{3,1}=(2+6+3)+15=27$ szt. Posiadając wielkość zamówienia, przedsiębiorstwo ze wzoru (2) oblicza wielkość planowanej produkcji [szt.]:

$$
Q_{1,1}=\frac{S_{1}}{T o}=\frac{27}{3}=9 .
$$

Przedsiębiorstwo produkuje produkt, wykorzystując dwa materiały. Dla każdego $\mathrm{z}$ materiałów tworzona jest rezerwa $\mathrm{w}$ wysokości $M 1_{0}=10, M 2_{0}=10$. Następnie, przy jednostkowym zużyciu materiałów $m_{M 1}=2, m_{M 2}=2$ oraz stałym cyklu składania zamówień $T_{M 1}{ }^{M D}=6, T_{M 2}{ }^{M D}=12$, ze wzoru (3) oblicza się wielkość dostawy każdego z materiałów, uwzględniając dodatkowo tworzone rezerwy: 


$$
\begin{aligned}
& M D_{1,1,1}=\sum_{t=1}^{6} Q_{t} m_{1}+M 1_{0}=52 \\
& M D_{1,2,1}=\sum_{t=1}^{12} Q_{t} m_{2}+M 2_{0}=166
\end{aligned}
$$

Koszty pracy ze wzoru (5) rozliczane są $\mathrm{w} t=g L$, a sprzedaż następuje tylko w $t=i T^{0}$, dlatego w $t=1$ zarówno $L C$, jak i $S$ wynosi 0 . W $t=0$ nie obserwuje się wpływów i wydatków gotówkowych.

Pierwszy wpływ gotówkowy pojawia się w $t=16$ - jest to wpływ z tytułu sprzedaży kredytowej dokonanej po cenie $p_{s}=4 \mathrm{w} t=3$ i wynosi zgodnie $\mathrm{z}(8)$ po korekcie o rezerwę stanu magazynu wyrobów gotowych $F G_{0}=15$ :

$$
C F_{16}^{+}=\left(S_{16-14+1}-F G_{0}\right) \cdot p_{s}=(27-15) \cdot 4=48 .
$$

\begin{tabular}{|c|c|c|c|c|c|c|c|c|c|c|c|c|c|c|}
\hline$t$ & $i$ & $j, r=1$ & $j, r=2$ & $g$ & $D_{t}$ & $Q_{t}$ & $M D^{M 1}$ & $M D^{M 2}$ & $S_{t, i}$ & $L C_{t, g}$ & $C F^{+}$ & $C F^{M 1-}$ & $C F^{M 2-}$ & $C F^{L-}$ \\
\hline 1 & 1 & 1 & 1 & 1 & 2 & 9 & 52 & 166 & 0 & 0 & 0 & 0 & 0 & 0 \\
\hline 2 & 1 & 1 & 1 & 1 & 4 & 9 & 0 & 0 & 0 & 0 & 0 & 0 & 0 & 0 \\
\hline 3 & 1 & 1 & 1 & 1 & 6 & 9 & 0 & 0 & 27 & 0 & 0 & 0 & 0 & 0 \\
\hline 4 & 2 & 1 & 1 & 1 & 8 & 10 & 0 & 0 & 0 & 0 & 0 & 0 & 0 & 0 \\
\hline 5 & 2 & 1 & 1 & 1 & 10 & 10 & 0 & 0 & 0 & 0 & 0 & 0 & 0 & 0 \\
\hline 6 & 2 & 1 & 1 & 1 & 12 & 10 & 0 & 0 & 30 & 0 & 0 & 52 & 0 & 0 \\
\hline 7 & 3 & 1 & 1 & 1 & 14 & 16 & 114 & 0 & 0 & 0 & 0 & 0 & 0 & 0 \\
\hline 8 & 3 & 2 & 1 & 1 & 16 & 16 & 0 & 0 & 0 & 0 & 0 & 0 & 0 & 0 \\
\hline 9 & 3 & 2 & 1 & 1 & 18 & 16 & 0 & 0 & 48 & 0 & 0 & 0 & 0 & 0 \\
\hline 10 & 4 & 2 & 1 & 1 & 20 & 22 & 0 & 0 & 0 & 0 & 0 & 0 & 166 & 0 \\
\hline 11 & 4 & 2 & 1 & 1 & 22 & 22 & 0 & 0 & 0 & 0 & 0 & 0 & 0 & 0 \\
\hline 12 & 4 & 2 & 1 & 1 & 24 & 22 & 0 & 0 & 66 & 0 & 0 & 114 & 0 & 0 \\
\hline 13 & 5 & 2 & 1 & 1 & 26 & 28 & 186 & 444 & 0 & 0 & 0 & 0 & 0 & 0 \\
\hline 14 & 5 & 3 & 2 & 1 & 28 & 28 & 0 & 0 & 0 & 0 & 0 & 0 & 0 & 0 \\
\hline 15 & 5 & 3 & 2 & 1 & 30 & 28 & 0 & 0 & 84 & 0 & 0 & 0 & 0 & 0 \\
\hline 16 & 6 & 3 & 2 & 1 & 32 & 34 & 0 & 0 & 0 & 0 & 48 & 0 & 0 & 0 \\
\hline 17 & 6 & 3 & 2 & 1 & 34 & 34 & 0 & 0 & 0 & 0 & 0 & 0 & 0 & 0 \\
\hline 18 & 6 & 3 & 2 & 1 & 36 & 34 & 0 & 0 & 102 & 0 & 0 & 186 & 0 & 0 \\
\hline 19 & 7 & 3 & 2 & 1 & 38 & 40 & 258 & 0 & 0 & 0 & 120 & 0 & 0 & 0 \\
\hline 20 & 7 & 4 & 2 & 1 & 40 & 40 & 0 & 0 & 0 & 437 & 0 & 0 & 0 & 0 \\
\hline 21 & 7 & 4 & 2 & 2 & 42 & 40 & 0 & 0 & 120 & 0 & 0 & 0 & 0 & 0 \\
\hline 22 & 8 & 4 & 2 & 2 & 44 & 46 & 0 & 0 & 0 & 0 & 192 & 0 & 444 & 0 \\
\hline 23 & 8 & 4 & 2 & 2 & 46 & 46 & 0 & 0 & 0 & 0 & 0 & 0 & 0 & 0 \\
\hline
\end{tabular}

Tabela 1. Wyniki deterministycznych symulacji na modelu operacyjnego kapitału obrotowego

Źródło: obliczenia własne. 
Wypływy gotówkowe związane $\mathrm{z}$ regulowaniem zobowiązań z tytułu dostaw materiałowych powstają odpowiednio dla $\mathrm{M} 1 \mathrm{w} t=6$, a dla M2 $\mathrm{w} t=10$. Wypływy związane z pokryciem wynagrodzenia za pracę pojawią się $\mathrm{w} t=30$ (jest to okres poza obszarem tab. 1) ze względu na odroczenie okresu regulowania zobowiązań z tytułu wynagrodzeń o $T^{L}=10$ dni. Wypływy gotówkowe wynoszą przy cenie materiałów $p_{m M 1}=1, p_{m M 2}=1$ zgodnie $\mathrm{z}(6)$ :

$$
\begin{aligned}
& C F_{6}^{M 1-}=1 \cdot M D_{6-6+1}^{M 1}=52 \\
& C F_{10}^{M 2-}=1 \cdot M D_{10-10+1}^{M 2}=166 .
\end{aligned}
$$

\section{Zakończenie}

W artykule przedstawiono budowę i weryfikację autorskiego finansowego modelu operacyjnego kapitału obrotowego, który skonstruowano, wykorzystując do tego celu podejście arkusza kalkulacyjnego. Scharakteryzowano model, przedstawiono jego założenia oraz równania. Ocenę modelu ze względu na możliwe ramy opracowania ograniczono do sprawdzenia poprawności zapisu matematycznego, który jednocześnie odpowiada formułom arkusza kalkulacyjnego Excel. Można uznać na tej podstawie, że model „działa” poprawnie.

Publikacja dotycząca oceny jakości modelu została rozłożona na części. W szczególności w kolejnych częściach konieczne jest opublikowanie wyników przeprowadzonej walidacji, tj. sprawdzenia zgodności zmiennych wyjściowych z definicjami operacyjnego kapitału obrotowego, oraz wyników oceny wiarygodności modelu, tj. sformułowania przesłanek pozwalających menedżerom na obdarzenie modelu zaufaniem koniecznym do wykorzystywania go w procesie decyzyjnym. Ostatecznie konieczne jest także dokonanie oceny możliwości aplikacyjnych modelu w praktyce zarządzania operacyjnym kapitałem obrotowym.

\section{Literatura}

Brealey R.A., Myers S.C., 1996, Principles of Corporate Finance, McGraw-Hill, New York.

Brigham F.E., Ehrhard M.C., 2008, Financial Management. Theory and Practice, Thomson, New York. Charnes J., 2007, Financial Modelling with Cristal Ball and Excel, Jon Wiley \& Sons, Hoboken.

Copeland T.E., Weston J.F., Shastri K., 2005, Financial Theory and Corporate Policy, Prentice Hall, Boston.

Kim Y., Chung K., 1984, An integrated evaluation of investment in inventory and credit: a cash flow approach, "Journal of Business Finance and Accounting", Vol. 17.

Pluta W., 2003, Planowanie finansowe w przedsiębiorstwie, PWE, Warszawa.

Sartoris W.L., Hill N.C., 1983, A generalized cash flow approach to short-term financial decisions, "Journal of Finance", May.

Szpulak A., 2014, Inwestycje netto w operacyjny kapitał obrotowy w rachunku przepływów pieniężnych, Prace Naukowe UE we Wrocławiu, pt. Zarzadzanie finansami firm-teoria i praktyka, nr 365.

Verminnen P. (2005), Corporate Finance. Theory and Practice, Jon Wiley \& Sons, Hoboken, s. 31. 


\title{
MODELING OF AN OPERATING WORKING CAPITAL - SPREADSHEET APPROACH. BUILDING AND MODEL VERIFICATION
}

\begin{abstract}
Summary: Typical financial model applied in the area of short term financial management under wealth maximization approach is in a form of an analytical model, like the one built by for example [Sartoris, Hill 1983; Kim, Chung 1990]. The assumptions concerning the continuous cash flows resulting from sales and direct relationship between the size of cash flows and the size of sales result in inaccurate and biased forecasts made on the basis of such analytical models. The applicability of it is therefore questionable. The paper presents the construction and verification of the financial model of operating working capital that enables to build forecasts of better quality. Such a goal is achieved by applying the spreadsheet approach instead of analytical functions.
\end{abstract}

Keywords: operating working capital, operating cash inflows and outflows, forecasts, spreadsheet approach. 